\title{
LESS OF THE ABSOLUTE, MORE OF THE PEDAGOGICAL. HANS BLUMENBERG AND EDUCATION
}

\begin{abstract}
The aim of this article is to consider the philosophy of Hans Blumenberg as potentially pedagogical thought. Hans Blumenberg's way of questioning can be juxtaposed with the Heideggerian way of questioning (much more popular in the philosophy of education) that starts with the human being as an ontologically distinguished creature. Blumenberg, unlike Heidegger, does not pursue the question of being as such, he consciously limits himself to anthropology, i.e. the humanity of being. Consequently, his anthropology is not fundamentally ontological, but contingent and culture-oriented. Blumenberg's phenomenological description of humanity concentrates on the ways humans deal with different modes of the absolute (not only theological, but also natural and political). It is a consequence of Blumenberg's anthropological statement concerning the human being as an underprivileged creature which compensates its natural shortcomings with culture (i.e. myths, metaphors, science, etc.), being able to make the absolute less predominant or rigorous, mitigating it in a way. This has humanistic and pedagogical import: the greater distance between us and absolute realities, the more space there is for human creativity and self-creativity, foremostly in the field of education.
\end{abstract}

Keywords: Blumenberg Hans, absolutism, education, myth, rhetoric, culture

1. Blumenberg's anthropological premises and juxtaposition with Heidegger's method. 2. The absolutism of reality versus myth. 3. Theological absolutism versus modern science. 4. Political absolutism versus rhetoric. 5. Conclusions.

In this article I would like to consider Hans Blumenberg as a thinker viable for educational thought. It is not because his work was devoted to education in any direct way. Just the opposite is the case, his remarks on education and teaching are rather scarce. Nevertheless, he seems to be one of those philosophers whose ways of thinking and reflection on humanity predestines his philosophical work to be pedagogically relevant in a broader sense. In order to present Blumenberg as a potentially educational thinker, I will briefly 
depict his conceptions of humanity and culture. In order to do this I describe, firstly, his basic anthropological premises and secondly, I will outline his philosophy of culture, his account of modernity and his approach to politics and rhetoric, the common denominator of these three being the relationship between human beings and absolute realities (nature, God, politics). Last but not least, I will develop some propositions concerning the specific pedagogical consequences of Hans Blumenberg's oeuvre.

\section{BLUMENBERG'S ANTHROPOLOGICAL PREMISES AND JUXTAPOSITION WITH HEIDEGGER'S METHOD}

In order to depict adequately the philosophical method of Hans Blumenberg and the consequences of his ways of thinking for the philosophy of education, it is sensible to briefly compare his point of departure with that of Heidegger and the general tendency of the pedagogical applications of his thought.

If we start to think philosophically on education with Heidegger, we encounter a serious methodological problem. We are inevitably bound to begin with the most "un-educationally" sounding question of the meaning of being as such. With other words, we need to root our analysis on an ontological basis. Of course, we could (as many philosophers of education do, in fact ${ }^{1}$ ) take a shortcut and abstract our analysis from the general ontological intention of Heidegger's early works and concentrate entirely on the description of Dasein. Which means, we can read Heidegger pedagogically as philosophical existential anthropology (e.g. asking what authenticity for education means). Nobody can say it is not legitimate, since Being and Time has been read as anthropology and existential philosophy by noneducational philosophers as well, which remained Heidegger's great

1 The reader will find some examples of this approach in: Heidegger, Education and Modernity, ed. M.A. Peters, Rowman Littlefield Publishers, Inc., Lahnam 2002. 
concern. Alas, by doing so, i.e. by taking advantage of the preparatory aspect of Heidegger's work, and by remaining oblivious to its deeper intention, we run the risk of misunderstanding and "shallowing" this work. It would be like - to put it metaphorically - taking his key to an ontological problem, unwilling to use it to open the door, but contemplating the key itself or adapting it in order to pick the lock of another door. This always happens to us, when we forget about the premise, that a human being is only an ontologically distinguished access to fundamental ontology. With Hans Blumenberg we are free of this risk.

Blumenberg's position is clearly openly anthropological. Unlike Heidegger, he has no ambition to make humanity an access to deeper ontological questions. Neither is he interested in being only as such (or, if he is, only as far as being can be critically conceived of as a version of deus absconditus). He does not put the question what it means to be, he rather puts the question of what it means to be human. It does not mean that Blumenberg's position is naive or that he is ignorant of all the philosophical problems with anthropology that only in the $20^{\text {th }}$ century started with transcendental phenomenology and ended with poststructuralism and posthumanism.

Blumenberg, in a constant struggle with phenomenology, is aware that the classical anthropological question of essence, "what is man?", is not tangible any more (as it was not for Heidegger). Nor does he ask, after Heidegger (like Hannah Arendt did), "who is man". Blumenberg's question sounds different, and yet somehow familiar: "How is man possible"? "What can he turn into?"

For Blumenberg, as for Heidegger, the most basic anthropological premise is the finite character of the human being (as opposed to the Husserlian absolute subject). In idealism and Husserlian phenomenology man is only an organ of reason. For Blumenberg it is the other way round: it is reason that is an organ of man. ${ }^{2}$ Primarily

2 H. Blumenberg, Beschreibung des Menschen, Suhrkamp, Tübingen 2006, 81. 
it is not given to us for the creation of great cultural achievements; it helps us to respond to the fundamental difficulties and challenges of life. As Franz Wetz puts it: "Blumenberg's attempt to develop a phenomenological anthropology undertakes to show that there are no such ultimate powers as the «absolute subject» or «reason as such» that could somehow be conceived independently of human beings themselves, and, in the second place, that all the higher faculties of man, such as disinterested contemplation, philosophical reflection, rational thought in general, are themselves cultural transformations of life-serving and life-promoting instruments deployed by finite human beings in their struggle for existence." 3

Rescuing the philosophical anthropology from Husserl's transcendental approach and turning towards the finitude of man is also a Heideggerian gesture. But here the similarities end. While Heidegger struggles to describe the existential structures of man in the light of the meaning of being and his (ontological) analysis is meant to be prior to any scientific approach (ontic), Blumenberg consistently reverses the traditional superior attitude of philosophy towards sciences: "The task of philosophy lies neither before, nor above, nor between the sciences; the most acceptable approach, I would suggest, is to locate the place of philosophy after the sciences." Blumenberg's anthropology was explicitly conceived as a superior alternative to Heidegger's approach. ${ }^{5} \mathrm{He}$ pursues and develops his phenomenological anthropology in relation to the findings of evolutionary biology. It does not mean that Blumenberg supports some sort of naturalism: he does not compete with the natural scientific explanation of life, nor does he try to add to it. What he offers is rather an existential description of the human being that science

3 F.J. Wetz, The Phenomenological Anthropology of Hans Blumenberg, Iris 1(2009)2, 394.

$4 \mathrm{H}$. Blumenberg, Beschreibung des Menschen, op. cit., 482. (This excerpt translated by F.J. Wetz, The Phenomenological Anthropology, op. cit., 395).

5 F.J. Wetz, The Phenomenological Anthropology, op. cit., 390. 
(mostly evolutionary biology) investigates. He exploits the results of the positive sciences for the development of anthropological investigations.

Blumenberg (sharing Herder's and Gehlen's views) describes man as a deficient being (Mängelwesen). Man can only preserve himself by compensating for his own biological defects (Gehlen's approach, for Blumenberg, is more fundamental than that of Heidegger, as survival is more fundamental than seeking for meaning). As already said, he avoids not only naturalism (the nature of man), but also any sort of essentialism (essence of man), by asking not what man is, but how man is possible in the first place. Although he refers to anthropogenesis, his answer is not biological or natural at all. The unlikely possibility of humanity consists in the human power of distancing himself from overwhelming reality (be it natural, theological, or political). This distance we call culture: sometimes it helps us to protect ourselves against nature, sometimes against human oppressive orders. This leads to a conception of humanity that creates itself against certain absolute powers, that, so to say, pushes away those powers in order to create some space for its own development. In Blumenberg's writings we find at least three basic powers that a human being needs to postpone, although not abolish: the absolute nature, the absolute god and the absolute political power. For each of them humans developed specific cultural tools to deal with, respectively: myth, science and rhetoric.

\section{THE ABSOLUTISM OF REALITY VERSUS MYTH}

Blumenberg's anthropological insight begins with a statement of original hostility and the indifference of the world towards humans. The overwhelming power of nature against a vulnerable creature Blumenberg names the absolutism of reality (Absolutismus der Wirklichkeit). It is the exact opposite of what philosophers called the life-world (Lebenswelt) that describes the world as a human 
creation, which is familiar, reliable and dependable for its creators (e.g. the description of being-in-the-world in Heidegger which conceives the world as a home full of useful tools that all refer to man, Dasein, at least as long as it is not filled with Angst). Both poles are theoretical constructs that help Blumenberg to grasp man as a being that constantly struggles to transform the hostile environment into the life-world. Thus, human culture is always somewhere in between those poles and strives to mollify the absolute of nature. It is the basic condition of human survival.

The need of this particular struggle is rooted in our biological evolutionary situation, that is the fact that only humans among living creatures developed a fully upright position. This fact has been interpreted philosophically since antiquity (as having its purpose in contemplating the heavens, partaking in the divine, being the master of the earth, or, as a sign of human dignity). But Blumenberg is not so much interested in quasi-theological or theological explanations. This is where evolutionary biology steps in. In Beschreibung des Menschen (Description of Man) Blumenberg meticulously tracked back the scientific findings concerning anthropogenesis. Here, it suffices to sum up their philosophical consequences: our ancestors lived in trees, which they abandoned for the open savannas as rain forests dwindled and they started to need the flesh of bigger animals. Their next home was the open space of grasslands and steppes. The upright position, the new living space, and the development of the hand were the most significant breakthroughs for humanity. Walking upright in the open space facilitates seeing further. But for the same reason, man can also be seen himself (it is a phenomenological anthropology in a literal sense: the human being as a phenomenon, a visible being ${ }^{6}$ ). Visibility means a considerable loss of natural protection. 
The cultural consequences of anthropogenesis Blumenberg develops mostly in Arbeit am Mythos (Work on Myth) ${ }^{7}$. The consciousness of our own visibility is a condition of reflection (here understood as appreciating one's own vulnerability, awareness of the possibility of being seen). But, leaving the forest, which allowed humans to see further to the horizons, helped to distance themselves from the closest reality and develop the power of anticipation (also by diminishing the role of the immediate senses such as taste and olfaction). The price for this, however, was fear. The new wider horizon becomes hostile and jeopardous. ${ }^{8}$ That is why humans protected themselves by hiding in holes and caves. Only the hunters ventured out of the cave while the most vulnerable ones, mothers and children, the weak, were hidden. This also meant a transition from immediate reaction to dominant tension. The means of dealing with fear had to be invented. It facilitated compromising the constant fear of what is not seen by telling stories about the unknown and hostile reality. In this way humans could feel a little more at home in the world by achieving distance, in the metaphorical sense of the term this time.

Myth, religion, and philosophical theories serve the purpose of reducing human fear of reality. Their function lies in the trick of replacing the unknown with the known (long before cognition is possible). It also replaces indefinite anxiety (Angst) of the unknown with a concrete fear. The first act is the act of giving names and metaphors to reality so that stories can be told. In this way the overwhelming chaos is divided into different powers that mitigate themselves. The function of myth is to translate the indefinite into the definite. It can be done by giving names to the overwhelming and indefinite natural powers. The perfect example being the cultural press of Homer and Hesiod, who divided nature into familiar names of gods with a clear message of their responsibilities. For instance,

7 H. Blumenberg, Arbeit am Mythos, Suhrkamp, Frankfurt am Main 2006.

8 Ibidem, 11-12. 
Zeus personifies the most important natural power, which - by virtue of this personification - is not unintelligible and completely arbitrary any more (a similar cultural press we can find also in Genesis). The division of natural powers and ascribing human features to them introduced them to the human world, which made them less absolute and more possible to cope with.

In this way, Blumenberg rejects the classical distinction between mythos and logos and undermines the understanding of logos as the next, more rational stage of human development after overcoming myth. For him myth is not an immature preparation for the work of logos or reason, but a result of the very precise work of logos. ${ }^{9}$

The important feature of myths is that they (unlike dogmas) are flexible, can be told and retold in many different versions. Arbeit am Mythos concentrates on one story that Blumenberg finds paradigmatic for the human search for distance from reality: it is the story of Prometheus. Blumenberg reconstructs all the versions from Aeschylus through Plato to Goethe and André Gide.

Why is that particular myth so important to make a leit-motif for Work on Myth? It not only takes part in creating distance through name and story, it is a particular story: Prometheus (which means "thinking in advance") is the only one of the Titans who lives in the epoch of Zeus and does not allow him to destroy the creatures of the Titans - humans. It reveals the possibility of mitigation of the power of Zeus and abolishes his indictment of humans. Humans become human because of the fire given by Prometheus, and they gain the right to existence denied to them by Zeus. For Blumenberg the whole history of human culture with education as its mainspring is promethean to the core. It is a history of sometimes peaceful dialogue and sometimes warring struggle with absolute nature, a constant attempt to weaken or postpone its hostile domination. Myths have

9 Ibidem, 18. 
to be told and retold in every generation to maintain their power of creating distance between men and nature.

The next step of creating distance from reality is concept. But concepts are, unlike myths, ambiguous. Apart from establishing freedom from reality, they can also create the oppressive power of dogmas.

\section{THEOLOGICAL ABSOLUTISM VERSUS MODERN SCIENCE}

It is not only natural reality that can be absolutist and oppressive for man. Another version of the absolute that needs mitigating measures is the monotheistic concept of God. Blumenberg deals with this kind of absolutism in his The Legitimacy of the Modern Age (Legitimität der Neuzeit $)^{10}$. The main agenda of the incredibly elaborate and minutely documented book is a philosophical defence of the autonomy of modernity against the many theoretical attacks on it, which tried to demonstrate that the modern age is only a continuation of Christianity or antiquity and lacks proper autonomy. Blumenberg's voluminous work is therefore directed against the secularization theses of Karl Löwith, Carl Schmitt, Eric Voegelin, or against the reversal of their point which can be found in the Heideggerian-like thesis of Hannah Arendt that modernity is a fundamental alienation from the world.

Blumenberg demonstrates that modernity is a new and autonomous historical epoch. He conceives modernity in Nietzschean terms as a self-assertion of man against the theological absolutism of the late middle ages.

It is not that monotheistic religion is, in Blumenberg's eyes, oppressive by nature. For instance, the scholastic doctrine of the Middle Ages delivered a vision of the teleologically organized world that was

$10 \mathrm{H}$. Blumenberg, The Legitimacy of the Modern Age, trans. by R. Wallace, The MIT Press, Cambridge MA 1983; H. Blumenberg, Die Legitimität der Neuzeit, Suhrkamp, Frankfurt am Main 1996. 
basically transparent to humans as infinite, but not indefinite chains of causes that ended in the First Cause (which is perspicuous in the demonstrations of God's existence in Thomas Aquinas). Nobody negated freedom and the omnipotence of God at that time, but the dramatic consequences for humans were not driven home. God's mind, with the essences of all things, guaranteed the order of things and the transparency of the world. Of course, the human mind is unable to conceptualize the essence of the universe, but it can humbly partake in God's knowledge. The main feature of such a God is not omnipotence, but benevolence: He allows human minds, to some extent, to fathom the mystery of the cosmos.

The situation changed dramatically towards the end of the Middle Ages, in $14^{\text {th }}$ century nominalism. The main figure of nominalism is Wilhelm Ockham with his insistence on the unlimited freedom and power of God. As a result, the order of creation becomes entirely one of contingency. The, thus far taken for granted, cause-effect structure of the cosmos becomes uncertain, in the way natural law becomes uncertain. Now everything depends on the arbitrary decisions of God. God can create in man an act of hostility towards Himself, and human responsibility and will become doubtful. Doubtful also becomes human's limited but certain cognition: now the omnipotent and free God can bring about that $2+2 \neq 4$. The scholastic, hierarchical and meaningful order of the universe with a benevolent and wise God as the Prime Mover is no longer manifest to humans. He becomes deus absconditus, the hidden God. These new theological circumstances freed humans from the certainties of the Aristotelian physics of theloi. This - according to Blumenberg - opens up a space for hypotheses and experiment.

The modern age, according to Blumenberg, is an answer to the nominalism of the late middle ages. Blumenberg's interpretation of modernity shifts the methodological accent from substance to function. The key concept will be that of reoccupation of positions (Umbesetzung): "What mainly occurred in the process 
that is interpreted as secularization (...) should be described not as a transposition of authentically theological contents into secularized alienation from their origin but rather as the reoccupation of answer positions that had become vacant and whose corresponding questions could not be eliminated."11 Early modernity is not a disguised continuation of the Middle Ages, but a reaction to the indifference of nominalistic God. Modernity means the opening of a new horizon of experiencing reality: a gradual renewal of the claim of unlimited theoretical curiosity.

The crux of the positive work of Blumenberg is a very thorough analysis of the centuries-long "trial" of human curiosity. The enlisting of curiosity as a vice started in late antiquity in the hellenistic and neoplatonic schools of skepticism and culminated with its submission to the rules of salvation in Tertullian at the turn of $2^{\text {nd }}$ and $3^{\text {rd }}$ centuries C.E. and later, ultimately, in St. Augustine. At the time it had the clear purpose of overcoming Gnosticism that identified cognition (specifically understood) with salvation. The conception of salvation totally independent of knowledge, cognition, and philosophical systems seemed to be a good answer for the danger of Gnosis.

Nominalistic voluntarism, in its turn, insisted so much on unpredictable predestination that even the promise of salvation became doubtful. Therefore, a new theoretical attitude had to assert man against the arbitrary power of God. Here is also the reason why the 17th century broke with traditional contemplation; that is why cognition gained a new function of projecting and verifying the possible, hypothetical constitution of phenomena. And that is also why one of the main figures of early modernity, Descartes, had to fight deus fallax, the malevolent God, and to establish a method independent of Him. The Galilean telescope became a symbol

$11 \mathrm{H}$. Blumenberg, The Legitimacy of the Modern Age, op. cit., 65. 
of the rehabilitation of theoretical curiosity and of the intellectual breakthrough of the new age.

Modernity and its new intellectual formation, is an act of selfdefense in the face of the powerlessness against the arbitrary will of a nominalistic God and unpredictable natural processes, analogous to the way myths and stories were acts of self-defense against the absolutism of reality. New science is not a function of a pure thirst for knowledge. It is a measure to transform the hostile world, once again, into a kind of safe place for humans. This also means a new space for human creation and self-creation: a new space between man and absolute reality. The absolute does not disappear, but it takes no part in human cognition, nor guarantees it any more. It is a new purely human space.

\section{POLITICAL ABSOLUTISM VERSUS RHETORIC}

The natural and theological absolutisms are not the only ones that can hinder human self-assertion and feeling at home in the world. The last version of absolutism is the absolute of human action, particularly the absolute of modern politics. The philosophy of politics is the weakest link in Blumenberg's impressive work. He wrote no separate book on the topic and his stance needs reconstruction from remarks, allusions, and polemics.

Blumenberg's concept of politics must be juxtaposed with two types of absolutist visions. The first we can symbolically call Platonism: it is a vision of politics as a servant of philosophy and the power of indisputable philosophical truth. The second is decisionism with its glorification of abrupt moments of action and sovereign decision in politics (Carl Schmitt). Both visions have one common feature: they despise "sheer words", i.e. rhetoric as a means of politics. For Plato and platonic philosophers, rhetoric is a synonym of sophism: a vicious game of words whose purpose is to disguise or distort, not to reveal, the truth. For decisionists like Schmitt, rhetoric is 
a synonym of endless parliamentary dispute that ravages a true and healthy democracy, based on sovereign decisions. This, of course, does not mean that they do not use rhetorical arguments themselves, for political theology is a rhetorical argument, as are the numerous after-life myths Plato referred to.

According to Blumenberg, rhetoric can be seen as a remedy for political violence: "Sometimes, and, perhaps, more and more often, practising politics 'in sheer words' appears to us benign." 12 The more global the politics we speak of, the more truthful these words are, for on a global scale politics is not management but political actions like conflicts and war.

But rhetoric has a wider, anthropological and educational significance in late modernity. Since humans cannot count on the eternal philosophical truths anymore, neither in metaphysics, nor in ethics, they do not have sufficient reasons for particular action. And still, sometimes they need to act. Blumenberg calls this condition a compulsion to act (Handlungszwang) without obviousness or sufficient reasons (Evidenzmangel), only with provisional norms. ${ }^{13}$ This is where rhetoric comes in: it provides the "insufficient reason" for human action.

This is particularly relevant in educational theory. As Blumenberg says: "Any kind of pedagogy is involved in practical action and cannot wait until the sufficient theoretical premises will be given." ${ }^{14}$ It becomes clear when we think of the goals of education. We need them in our theories of educational action, otherwise we would reduce those theories to a mere set of technical rules. But we cannot "prove" them

12 H. Blumenberg, Wirklichkeitsbegriff und Staatstheorie, Schweizer Monatshefte: Zeitschrift für Politik, Wirtschaft, Kultur 48(1968-1969), 129.

13 H. Blumenberg, Anthropologische Annäherung an die Aktualität der Rhetorik, in: Ästhetische und metaphorologische Schriften, ed. A. Haverkamp, Suhrkamp, Frankfurt am Main 2001, 413-417.

14 H. Blumenberg, Anthropologische Annäherung an die Aktualität der Rhetorik, op. cit., 424. 
by using the scientific method because they are not verifiable logical propositions. Nevertheless they are unavoidable in any educational theory. Modern pedagogy strives at defining the goals and objectives in a very specific way, so as to remove this uncanny feature of lack of obviousness and verifiability. A good example could be the socalled "learning outcomes" in our curricula, which are supposed to be demonstrable and measurable. Sometimes our educational goals are consciously designed to be general and elusive, like in Wilhelm von Humboldt's Theorie der Bildung des Menschen (Theory of Human Education), which was written in about 1793 . Here he states that "the ultimate task of our existence is to give the fullest possible content to the concept of humanity in our own person (...) through the impact of actions in our own lives." 15 The first, "definite" or "operational" way of describing our educational goals strives at avoiding the rhetorical load, evident in the traditional, open ways of defining them. But they turn out to be as rhetorical as openly "indefinite" objectives of traditional educational theorists, like Humboldt. They suffer from the same Evidenzmangel and Handelszwang, the only difference being that the technical language in which they are formulated aims at covering their essential insufficiency.

One of the pedagogical lessons we can learn from Blumenberg is that we need this rhetoric of goals, however it will always be theoretically insufficient. Maybe, I am following Lynda Stone here, it is time to embrace the rhetorical nature of education instead of constantly subduing it to scientism. ${ }^{16}$

On the other hand, rhetoric also has the opposite pedagogical function. It can not only support action, it can also replace it (like in global politics) or delay its immediacy, mitigate the compulsion

15 W. von Humboldt, Theorie der Bildung des Menschen. Bruchstück, in: Werke in 5 Bänden, Band I, Schriften zur Anthropologie und Geschichte, Wissenschaftliche Buchgesellschaft, Darmstadt 1960, 235-236.

16 L. Stone, A Rhetorical Revolution for the Philosophy of Education, Philosophy of Education Archive (1996). 
of action. In this sense rhetoric functions as the opposite to terror, violence and a technical shrinking of action. ${ }^{17}$ As Claude Monod puts it: "Blumenberg's view of rhetoric lies upon an opposition between, on one side, language, and maybe more specifically dialogue, and, on the other side, violence - an opposition, known since Socrates as that of logos and bia (force), which is as old as philosophy and democracy." ${ }^{18}$ Blumenberg is not one of those philosophers afraid of modern technology or its essence (like Heidegger seemed to be). Technology, as one of the measures to deal with reality, is justified. "The danger that Blumenberg sees lies rather in the naturalization of the technological, in the comprehensive transformation of the technological into the second nature."19 Blumenberg's concern here focuses on education, or more specifically, on its tendency to train functional executors, not to educate people who know what they are doing. This tendency is reflected in the modern educational rhetoric of getting rid of "unnecessary material" that overburdens the poor children and in the mentioned technological rhetoric of "learning outcomes". This means that human action can be - also through education - gradually reduced to instant reaction to impulses. One of the most important tasks of education is, according to Blumenberg, delaying the functional relation between the signal and reaction to it and saving the cultural distance between human beings and reality. ${ }^{20}$

17 H. Blumenberg, Anthropologische Annäherung an die Aktualität der Rhetorik, op. cit., 416.

18 C. Monod, A rhetorical approach of politics: Blumenberg's principle of insufficient reason and its pascalian consequences, a lecture from December 8, 2008, 14.

19 K. Mayer-Drawe, Die Veränderung Pädagogischen Denkens, in: Hans Blumenberg: Pädagogische Lektüren, ed. F. Ragutt, T. Zumhoff, Springer, Wiesbaden 2016, 188.

$20 \mathrm{H}$. Blumenberg, Anthropologische Annäherung an die Aktualität der Rhetorik, op. cit., 421-422. 


\section{CONCLUSIONS}

The pedagogical value of Blumenberg's writings is, of course, not limited to his scant remarks on education. This article aimed at demonstrating the exact opposite: Blumenberg's anthropology is, though in a rather potential way, pedagogical to the core. First of all, apart from its quasi-biological premises, this anthropology is never naturalistic; neither is it metaphysical (there is no "human nature" in its positive vocabulary). Instead, it stresses the ability of men to create a free space in the dense or perilous reality of the absolute. Therefore, the role of anthropology is rather exposing what is, seemingly, "natural". ${ }^{21}$

Individual education, is, in a way, the repetition of the history of human consciousness since the times of anthropogenesis. Therefore, its purpose can be described as searching for distance and preventing compulsion in human life. It can be a compulsion of nature, it can also be a compulsion created by humans themselves: theological or political absolutisms, or the shrinking of distance in modern technology and reducing human action to automatic responses. Cultural anthropogenesis means pushing away the absolute in order to gain the possibility of self-creation: be it through myth, science, rhetoric or metaphor. In short, the pedagogical meaning of Blumenberg can be summarized succinctly: "Less of the absolute, more self-creation, more culture, more education.”

\section{REFERENCES}

Blumenberg H., Wirklichkeitsbegriff und Staatstheorie, Schweizer Monatshefte: Zeitschrift für Politik, Wirtschaft, Kultur 48(1968-1969), 120-146.

Blumenberg H., Anthropologische Annäherung an die Aktualität der Rhetorik, in: Ästhetische und metaphorologische Schriften, ed. A. Haverkamp, Suhrkamp, Frankfurt am Main 2001. 
Blumenberg H., Arbeit am Mythos, Suhrkamp, Frankfurt am Main 2006.

Blumenberg H., Beschreibung des Menschen, Suhrkamp, Tübingen 2006.

Blumenberg H., Die Legitimität der Neuzeit, Suhrkamp, Frankfurt am Main 1996.

Blumenberg H., The Legitimacy of the Modern Age, transl. by R. Wallace, The MIT Press, Cambridge MA 1983.

Heidegger, Education and Modernity, ed. M.A. Peters, Rowman Littlefield Publishers, Inc., Lahnam 2002.

Humboldt W. von, Theorie der Bildung des Menschen. Bruchstück, in : Werke in 5 Bänden, Band I, Schriften zur Anthropologie und Geschichte, Wissenschaftliche Buchgesellschaft, Darmstadt 1960.

Mayer-Drawe K., Die Veränderung Pädagogischen Denkens, in: Hans Blumenberg: Pädagogische Lektüren, ed. F. Ragutt, T. Zumhoff, Springer, Wiesbaden 2016, 181-195.

Monod C., A rhetorical approach of politics: Blumenberg's principle of insufficient reason and its pascalian consequences, a lecture delivered December 8, 2008.

Stone L., A Rhetorical Revolution for the Philosophy of Education, Philosophy of Education Archive (1996), 412-420.

Wetz F.J., The Phenomenological Anthropology of Hans Blumenberg, Iris 1(2009)2, 389-414.

\footnotetext{
PAULINA SOSNOWSKA

psosnowska@uw.edu.pl

Warsaw University, Faculty of Education

Mokotowska 16/20, 00-561 Warsaw, Poland

DOI: 10.21697/spch.2018.54.4.03
} 